\title{
Ventilation heat loss in a multifamily building under varying air density
}

Piotr MICHALAK

DOI: 10.30464/jmee.2020.4.1.97

Cite this article as:

Michalak P. Ventilation heat loss in a multifamily building under varying air density. Journal of Mechanical and Energy Engineering, Vol. 4(44), No. 1, 2020, pp. 97-102.

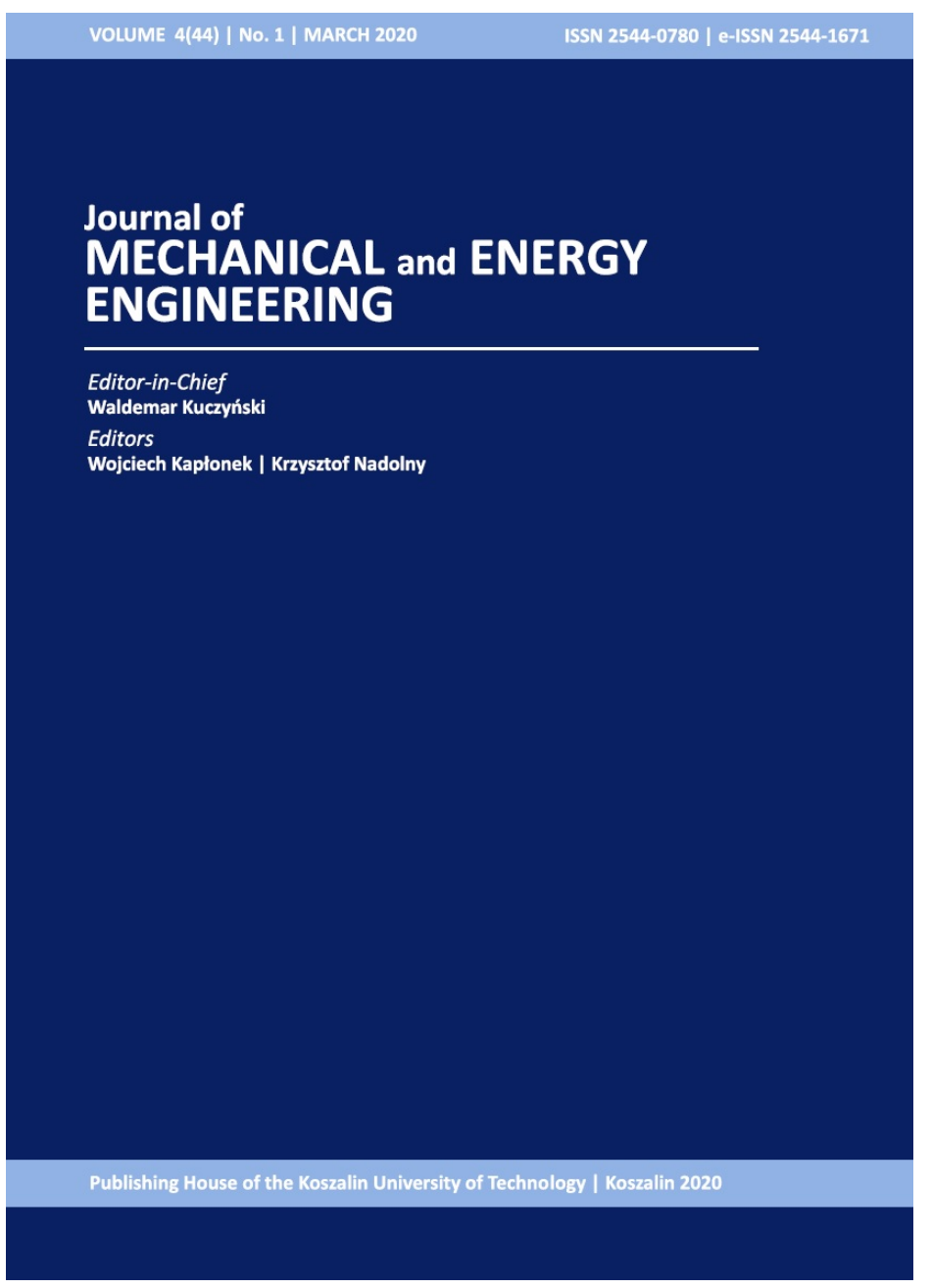

Journal of Mechanical and Energy Engineering

Website: jmee.tu.koszalin.pl

ISSN (Print): 2544-0780

ISSN (Online): 2544-1671

Volume: $4(44)$

Number: 1

Year: 2020

Pages: 97-102

Article Info:

Received 19 March 2020

Accepted 27 March 2020

\section{Open Access}

This article is distributed under the terms of the Creative Commons Attribution 4.0 (CC BY 4.0) International License (http://creativecommons.org/licenses/by/4.0/), which permits unrestricted use, distribution, and reproduction in any medium, provided you give appropriate credit to the original author(s) and the source, provide a link to the Creative Commons license, and indicate if changes were made. 


\title{
VENTILATION HEAT LOSS IN A MULTIFAMILY BUILDING UNDER VARYING AIR DENSITY
}

\author{
Piotr MICHALAK ${ }^{1 *}$ \\ ${ }^{1 *}$ Faculty of Mechanical Engineering and Robotics, Department of Power Systems and Environmental \\ Protection Facilities, AGH University of Science and Technology, Mickiewicza 30, 30-059 Kraków, Poland, \\ e-mail: pmichal@agh.edu.pl
}

(Received 19 March 2020, Accepted 27 March 2020)

\begin{abstract}
Standards related to calculation methods used in building energy performance simulation tools usually impose constant volumetric heat capacity of air. However, this simplification may result in errors if the actual conditions differ from the assumptions made. The paper presents the problem of dry air density and specific heat capacity variation and their influence on calculated energy use for space heating in a multifamily building. The monthly calculation method of PN-EN ISO 13790 was used. Simulations were performed in five cities, each in one climatic zone according to PN-EN 12831. Variation of the air density caused by air temperature and elevation resulted in differences in calculated heating demand from $-4.5 \%$ to $4.5 \%$ in relation to that at constant volumetric heat capacity assumed in PN-EN ISO 13790.
\end{abstract}

Keywords: air density, heat capacity of dry air, volumetric heat capacity, ventilation heat loss, EN ISO 13790 , monthly method

\section{INTRODUCTION}

Poland is the country with heating dominated climate [1-3]. Thus, energy use for space heating has significant share in total energy consumption in Polish buildings. One of the elements influencing heating demand is the ventilation (including ventilation and infiltration) heat loss [4-6]. Its importance increases with new standards [7], both in low-energy and passive [8] as well as in thermally refurbished objects [9]. This is so, because the main task of ventilation is to provide fresh air and to remove used air independently on the energy standard of a building.

Mathematical models applied in simulation tools used in energy auditing, design or certification of buildings commonly assume constant air density and specific heat capacity. But varying outdoor conditions cause these parameters to change.

This paper presents an assessment of the impact of the air density on the ventilation heat loss and resulting heating demand of a multifamily residential building in five cities, each in different Polish climatic zone. Calculations were performed using the monthly method of PN-EN ISO 13790 [10]. The ventilation heat loss was determined at constant volumetric heat capacity of air of $1200 \mathrm{~J} / \mathrm{m}^{3} \cdot \mathrm{K}$, imposed in that standard, and comparatively at monthly outdoor air temperatures from monthly weather data.

\section{VOLUMETRIC HEAT CAPACITY OF DRY AIR}

\subsection{Introduction}

Calculation methods of PN-EN ISO 13790 to assess thermal performance of buildings don't take into account humidification or dehumidification processes. Hence, basic properties of dry air are described briefly in the following paragraphs.

\subsection{Air density}

Within the air temperature and atmospheric pressure variation met in climatic conditions of Europe it is sufficient to treat atmospheric air as ideal gas [11]. Hence, assuming current recommendations [12-14], it can be calculated that the density of dry air at standard conditions $(T O=273.15 \mathrm{~K}, p O=100 \mathrm{kPa})$ is $\rho 0=1.27540 \mathrm{~kg} / \mathrm{m}^{3}$ and varies from $1.43276 \mathrm{~kg} / \mathrm{m}^{3}$ at $-30^{\circ} \mathrm{C}$ to $1.14918 \mathrm{~kg} / \mathrm{m}^{3}$ at $+30^{\circ} \mathrm{C}$, i.e. decreases by $20 \%$.

Atmospheric pressure has slightly less significant, but still noticeable, impact on air density. At $0^{\circ} \mathrm{C} \rho_{a}$ rises from $1.21163 \mathrm{~kg} / \mathrm{m}^{3}$ at $950 \mathrm{hPa}$ to $1.33917 \mathrm{~kg} / \mathrm{m}^{3}$ at $1050 \mathrm{hPa}$, i.e. by $11 \%$ (Fig. 1). 


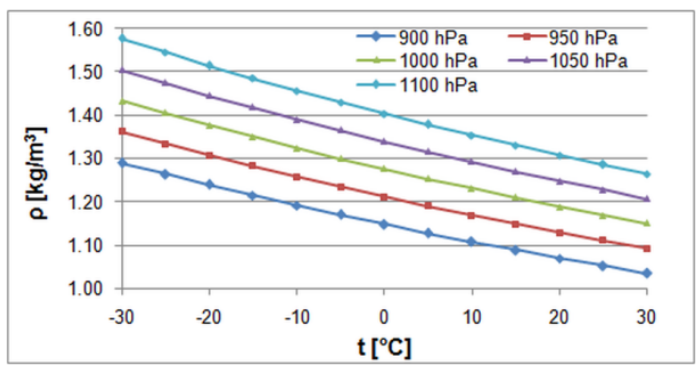

Fig. 1. Air density for different temperatures and pressures

If only temperature measurements are available, the air density at the known elevation can be calculated from the barometric formula $[15,16]$ at constant temperature (isothermal atmosphere):

$$
\rho_{a, h}=\rho_{0} \cdot \exp \left(-g \cdot h / R \cdot T_{0}\right) .
$$

As a reference point typically standard conditions are used. From this:

$$
\rho_{a, h}=1.2754 \cdot \exp (-h / 7995.29) .
$$

In such a case the air density depends only on the air temperature $(\mathrm{T})$ on site:

$$
\rho_{a}(T)=\rho_{a, h} \cdot T_{0} / T .
$$

\subsection{Specific heat capacity}

Specific heat capacity of dry air in the temperature range from $-50^{\circ} \mathrm{C}$ to $+50^{\circ} \mathrm{C}$ at $p=100 \mathrm{kPa}$ changes from $c_{a}=1006.1 \mathrm{~J} / \mathrm{kg} \cdot \mathrm{K}$ to $1007.7 \mathrm{~J} / \mathrm{kg} \cdot \mathrm{K}$, with the minimum of $1005.7 \mathrm{~J} / \mathrm{kg} \cdot \mathrm{K}$ at $-20^{\circ} \mathrm{C}$ (Fig. 2).

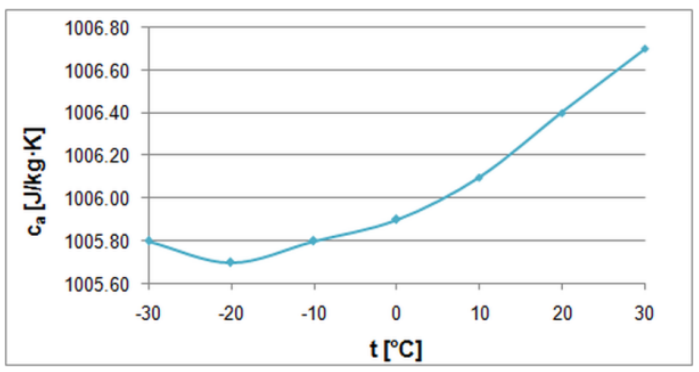

Fig. 2. Specific heat capacity of air at $p=100 \mathrm{kPa}[17]$

Atmospheric pressure has negligible effect on $c_{a}$. For example, at $0^{\circ} \mathrm{C} c_{a}=1005.9 \mathrm{~J} / \mathrm{kg} \cdot \mathrm{K}$ and 1013.9 $\mathrm{J} / \mathrm{kg} \cdot \mathrm{K}$ at $100 \mathrm{kPa}$ and $500 \mathrm{kPa}$, respectively. Hence, it seems appropriate to accept $c_{a}=1006 \mathrm{~J} / \mathrm{kg} \cdot \mathrm{K}$ for energy simulations of buildings.

\section{MATERIALS AND METHODS}

\subsection{Monthly method of PN-EN ISO 13790}

To assess the thermal performance of buildings in Poland commonly monthly method of PN-EN ISO 13790 is used. This standard has been replaced by PN-EN ISO 52016 recently [18] but the monthly calculation method remained the same in essence [19]. In spite of its simplicity that method provides correct results [20] and therefore was commonly introduced in national regulations [21].

Thermal balance of a building zone consists of heat losses and heat gains. Heat losses include heat transfer by transmission and by ventilation:

$$
Q_{H, h t}=Q_{H, t r}+Q_{H, v e} .
$$

Heat gains include solar gains and heat gains from internal sources (occupants, appliances, lighting, tap water and recoverable system thermal losses):

$$
Q_{H, g n}=Q_{H, \text { sol }}+Q_{H, i n t} .
$$

Calculation of thermal balance over one month takes into account dynamic effects by means of the gain utilization factor for heating. The monthly energy demand for space heating, $Q_{H, n d}$, is given by:

$$
Q_{H, n d}=Q_{H, h t}-\eta_{H, g n} \cdot Q_{H, g n} .
$$

For a given month the gain utilisation factor for heating, $\eta_{H, g n}$, depends on the relation between heat gains and heat losses:

$$
\gamma_{H}=Q_{H, g n} / Q_{H, h t}
$$

If $\gamma_{H}>0$ and $\gamma_{H} \neq 1$ :

$$
\eta_{H, g n}=\frac{1-\gamma_{H}^{\alpha_{H}}}{1-\gamma_{H}^{\alpha_{H}+1}} .
$$

If $\gamma_{H}=1$ :

$$
\eta_{H, g n}=\alpha_{H} /\left(\alpha_{H}+1\right)
$$

else if $\gamma_{H}<1$ :

$$
\eta_{H, g n}=1 / \gamma_{H},
$$

with:

$$
\alpha_{H}=\alpha_{H, 0}+\tau / \tau_{H, 0}
$$

In Poland normative default values of $\alpha_{H, 0}=1 \mathrm{~h}$ and $\tau_{H, 0}=15 \mathrm{~h}$ are used.

The time constant of a building depends on its internal heat capacity and overall heat transfer coefficients by transmission and by ventilation:

$$
\tau=C_{m} /\left(H_{t r}+H_{v e}\right)
$$

\subsection{Ventilation heat loss}

For a given thermal zone and time period the total heat loss by ventilation (including air infiltration and ventilation) for heating is calculated from the formula:

$$
Q_{H, v e}=H_{v e} \cdot\left(t_{\mathrm{int}, s e t . H}-t_{e}\right) \cdot \Delta \tau,
$$

with:

$$
H_{v e}=\rho_{a} \cdot c_{a} \cdot \dot{v}_{v e}
$$

PN-EN ISO 13790 imposed $\rho_{a} \cdot c_{a}=1200 \mathrm{~J} / \mathrm{m}^{3} \cdot \mathrm{K}$. Assuming $c_{a}=1006 \mathrm{~J} / \mathrm{kg} \cdot \mathrm{K}$ (see Section 2.3.) at the pressure of $100 \mathrm{kPa}$ the resulting air temperature is 
$18.9^{\circ} \mathrm{C}$. It differs significantly from the average annual outdoor air temperature in Poland $[22,23]$ of about $8^{\circ} \mathrm{C}$, at which fresh air is delivered to interior of buildings via infiltration and ventilation.

\subsection{Typical meteorological years}

Files with typical meteorological years [24] (TMYs) were introduced in Poland in 2008 for building simulations along with the implementation of the Directive on Energy Performance of Buildings (EPBD). They have been prepared for 61 weather stations in Poland in hourly and monthly formats. Monthly data include month number, minimum, maximum and average air temperature (dry bulb), sky temperature, global solar irradiance on a horizontal surface and on sloped surfaces $\left(30^{\circ}, 45^{\circ}, 60^{\circ}\right.$ and $\left.90^{\circ}\right)$ oriented in eight basic directions (N, NE, E, SE, S, SW, W and NW), the code and the name of the World Meteorological Organization (WMO) station. Hourly data include also day, hour (UTC time), relative humidity, moisture content, wind speed and wind direction. In addition north latitude, east longitude, elevation above sea level, time zone from 0 to east, number of days of meteorological data and the version number of a file are also given.

\section{CAlculations}

\subsection{Building}

To perform necessary simulations a model of a multifamily building was used (Fig. 3).

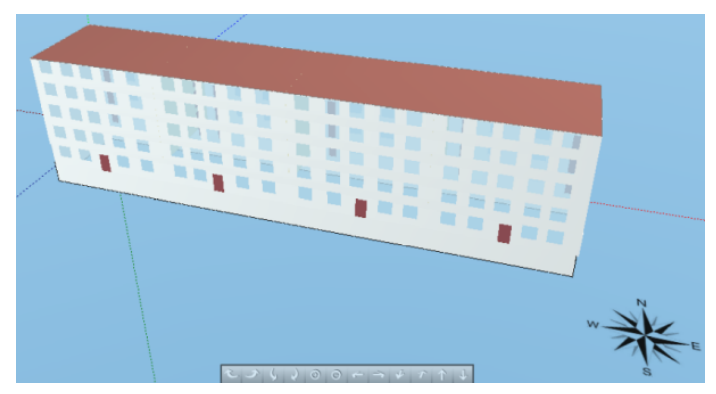

Fig. 3. View of the building in the Audytor OZC program

It has been built on a rectangular plan of $60 \mathrm{~m}$ and $11 \mathrm{~m}$. Thermal resistances of external walls and roof are $4.048 \mathrm{~m}^{2} \cdot \mathrm{K} / \mathrm{W}$ and $4.885 \mathrm{~m}^{2} \cdot \mathrm{K} / \mathrm{W}$, respectively.

Its main parameters are shown in Table 1 . The design ventilation airflow was set in standard conditions. The thermal capacity of the building, $C_{m}$, was obtained from physical properties of materials using simple method from PN-EN ISO 13786 [25]. Additional data were given in [2].

\subsection{Test locations}

The PN-EN 12831 standard [26] defines five zones for calculation of the design heat load in Poland $[27,28]$. Five locations were chosen for further simulations, one in each zone, as listed in Table 2.
Tab. 1. General characteristics of the building

\begin{tabular}{lcc}
\hline Parameter & Value & Unit \\
\hline Height above the ground & 13.6 & $\mathrm{~m}$ \\
\hline Total heated area & 2991.5 & $\mathrm{~m}^{2}$ \\
\hline Total heated volume & 7478.8 & $\mathrm{~m}^{3}$ \\
\hline $\begin{array}{l}\text { Heat transfer coefficient by } \\
\text { transmission }\left(\mathrm{H}_{\mathrm{tr}}\right)\end{array}$ & $1324.6 \mathrm{~W} / \mathrm{K}$ \\
\hline Internal heat capacity $\mathrm{C}_{\mathrm{m}}$ & $777.8 \mathrm{MJ} / \mathrm{K}$ \\
\hline $\begin{array}{l}\text { Internal heat gains density per } \\
\text { floor area }\end{array}$ & $4.0 \mathrm{~W} / \mathrm{m}^{2}$ \\
\hline Design ventilation airflow & $7478.8 \mathrm{~m}^{3} / \mathrm{h}$ \\
\hline External wall area - N & $816.0 \mathrm{~m}^{2}$ \\
\hline External wall area - S & $816.0 \mathrm{~m}^{2}$ \\
\hline External wall area - E & $149.6 \mathrm{~m}^{2}$ \\
\hline External wall area - W & $149.6 \mathrm{~m}^{2}$ \\
\hline Area of windows - N & $172.8 \mathrm{~m}^{2}$ \\
\hline Area of windows - S & $127.2 \mathrm{~m}^{2}$ \\
\hline Area of windows - E & $0.0 \mathrm{~m}^{2}$ \\
\hline Area of windows - W & $0.0 \mathrm{~m}^{2}$ \\
\hline Area of the roof & $660.0 \mathrm{~m}^{2}$ \\
\hline
\end{tabular}

Tab. 2. Chosen test locations

\begin{tabular}{lcccc}
\hline Location & Zone & $\begin{array}{c}\text { North } \\
\text { latitude }\end{array}$ & $\begin{array}{c}\text { East } \\
\text { longitude }\end{array}$ & $\begin{array}{c}\text { Elevation } \\
{[\mathrm{m}]}\end{array}$ \\
\hline Koszalin & I & $54^{\circ} 12^{\prime}$ & $16^{\circ} 09^{\prime}$ & 34 \\
\hline Poznań & II & $52^{\circ} 25^{\prime}$ & $16^{\circ} 51^{\prime}$ & 84 \\
\hline Kielce & III & $50^{\circ} 49^{\prime}$ & $20^{\circ} 42^{\prime}$ & 261 \\
\hline Terespol & IV & $52^{\circ} 04^{\prime}$ & $23^{\circ} 37^{\prime}$ & 137 \\
\hline Zakopane & V & $49^{\circ} 18^{\prime}$ & $19^{\circ} 58^{\prime}$ & 857 \\
\hline
\end{tabular}

Applying Eq. (2) air density at standard conditions was calculated for the given elevation. From this, assuming $c_{a}=1006 \mathrm{~J} / \mathrm{kg} \cdot \mathrm{K}$ and taking annual average air temperatures ( $\mathrm{T}$ in Eq. (3)) from weather files, volumetric heat capacity of air was determined. Additionally, the relative percentage error of approximation of calculated volumetric heat capacity of air with that of EN ISO 13790 was calculated.

Tab. 3. Volumetric heat capacity at annual temperature

\begin{tabular}{ccccc}
\hline Location & $\begin{array}{c}\mathrm{t}_{\mathrm{a}} \\
{\left[{ }^{\circ} \mathrm{C}\right]}\end{array}$ & $\begin{array}{c}\rho_{\mathrm{a}, \mathrm{h}}\left(\mathrm{t}_{\mathrm{a}}\right) \\
{\left[\mathrm{kg} / \mathrm{m}^{3}\right]}\end{array}$ & $\begin{array}{c}\rho_{\mathrm{a}, \mathrm{h}}\left(\mathrm{t}_{\mathrm{a}}\right) \cdot \mathrm{c}_{\mathrm{a}} \\
{\left[\mathrm{J} / \mathrm{m}^{3} \cdot \mathrm{K}\right]}\end{array}$ & $\varepsilon[\%]$ \\
\hline Koszalin & 7.95 & 1.2700 & 1241.5 & -3.34 \\
\hline Poznań & 8.21 & 1.2621 & 1232.6 & -2.64 \\
\hline Kielce & 7.51 & 1.2344 & 1208.6 & -0.71 \\
\hline Terespol & 7.76 & 1.2537 & 1226.4 & -2.15 \\
\hline Zakopane & 5.43 & 1.1458 & 1130.2 & 6.18 \\
\hline
\end{tabular}


Results presented in Table 3 show differences between volumetric heat capacities from two methods. Thus, further calculations of heating demand of the described building in subsequent months of a year were performed in each location.

\subsection{Heating demand of the building}

Applying the monthly method described in Section 3.1. with proper weather data monthly energy use for space heating of the building was calculated.

Using PN-EN ISO 13790 (first method) at constant $\rho_{\mathrm{a}} \cdot \mathrm{c}_{\mathrm{a}}=1200 \mathrm{~J} / \mathrm{m}^{3} \cdot \mathrm{K}$ annual heating demand (Fig. 4) was from $880.41 \mathrm{GJ}$ in Koszalin to 1059.91 GJ in Zakopane. The second method provided results from $923.00 \mathrm{GJ}$ to 1012.43 GJ.

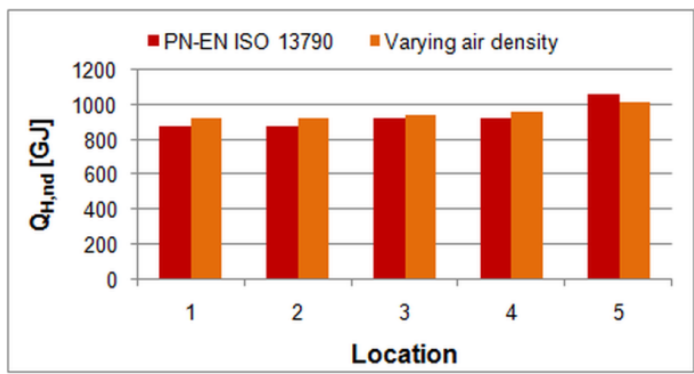

Fig. 4. Calculated annual heating demand

In three cases $(1,2,4)$ the new method gave higher values of $Q H, n d$, by $4.5 \%$ on average. Relatively low elevations of these cities didn't significantly reduce the air density. Air temperature in cold half year, from X to III, was lower than $18.9^{\circ} \mathrm{C}$ (see Section 3.2.) and finally volumetric heat capacity was higher than $1200 \mathrm{~J} / \mathrm{m} 3 \cdot \mathrm{K}$ resulting in greater ventilation heat loss.

Different situation was observed in locations 3 and 5. The air density calculated in Zakopane (5-th case) at elevation of $857 \mathrm{~m}$ (Eq. 2) and $\mathrm{T}_{0}$ was $\rho_{a, h}=1.1458$ $\mathrm{kg} / \mathrm{m}^{3}$, i.e. lower by $10.2 \%$ from $\rho_{0}$.

In case of the 3-rd location reduction of air density due to elevation was compensated by lower temperature during heating season. That's why the difference in $Q_{H}$ amounted only $1.5 \%$.

Differences in $Q_{H, n d}$ should be also considered in terms of heating energy consumption per floor area (EA). This is very important indicator from the point of view of energy certification of buildings [29, 30]. The second method resulted in EA from $4.0 \mathrm{kWh} / \mathrm{m}^{2}$ higher (Koszalin) to $4.4 \mathrm{kWh} / \mathrm{m}^{2}$ lower (Zakopane) than the first one.

\section{CONCLUSIONS}

Varying environmental conditions, especially air temperature and barometric pressure, influence air density and ventilation heat loss in each building.

The monthly calculation method of PN-EN ISO 13790 was used to determine heating demand of a multifamily building in five Polish cities. Air density variation caused by changes in air temperature and elevation above sea level was described by the ideal gas law and barometric formulas, respectively.

Performed calculations revealed differences in the annual heating demand between two methods and confirmed its dependence on the aforementioned factors. In addition, previous works [2, 31] indicated strong impact of the new PN-EN ISO 52010 standard on calculated solar gains in buildings, comparing to the method used so far, influencing values of heating and cooling demand without any physical changes in the building's structure. This is a premise for a detailed study about the calculation procedures used in the energy calculations of buildings.

\section{Nomenclature}

$$
\begin{aligned}
& \text { Symbols } \\
& g \quad \text { - gravitational acceleration, } g=9.80665 \mathrm{~m} / \mathrm{s}^{2} \\
& h \quad \text { - elevation above sea level (altitude), } \mathrm{m} \\
& t_{a} \quad \text { - mean annual temperature of external air, }{ }^{\circ} \mathrm{C} \\
& t_{\text {int }, \text { set }, H} \quad \text { - internal air temperature for heating, }{ }^{\circ} \mathrm{C} \\
& t \quad \text { - external air temperature, }{ }^{\circ} \mathrm{C} \\
& \dot{v}_{v e} \quad \text { - ventilation and infiltration airflow rate, } \mathrm{m}^{3} / \mathrm{s} \\
& C_{m} \quad \text { - internal thermal capacity of the considered } \\
& \text { building (or zone), } \mathrm{J} / \mathrm{K} \\
& E_{A} \quad-\quad \text { annual heating energy demand per conditioned } \\
& \text { unit floor area of a building, } \mathrm{kWh} / \mathrm{m}^{2}
\end{aligned}
$$

\section{Greek letters}

$\alpha_{H} \quad$ - numerical parameter for the heating mode, -

$\alpha_{H, O} \quad$ - reference numerical parameter for the heating mode, $\alpha_{\mathrm{H}, 0}=1.0$

$\gamma_{H} \quad-$ heat gain ratio for heating, -

$\varepsilon \quad$ - relative percentage error, $\%$

$\eta_{H, \mathrm{gn}} \quad$ - gain utilization factor for heating, -

$\Delta \tau \quad$ - calculation time period, $\mathrm{h}$

$\tau \quad$ - time constant of the building, $\mathrm{h}$

$\tau_{H, 0} \quad$ - reference time constant for heating, $\tau_{\mathrm{H}, 0}=15 \mathrm{~h}$

$\rho_{a, h} \quad$ - density of dry air at the given elevation $h, \mathrm{~kg} / \mathrm{m}^{3}$

$\rho_{a}(T) \quad$ - air density at the given temperature $T, \mathrm{~kg} / \mathrm{m}^{3}$

$\rho_{0} \quad-\quad$ air density at standard conditions $\left(\mathrm{T}_{0}=273.15\right.$

$\left.\mathrm{K}, \mathrm{p}_{0}=100 \mathrm{kPa}\right), \rho_{0}=1.27540 \mathrm{~kg} / \mathrm{m}^{3}$

molar mass of dry air, $\mu=28.96546 \mathrm{~g} / \mathrm{mol}$

\section{References}

1. H. Jędrzejuk, O. Dybiński. (2015). The influence of a heating system control program and thermal mass of external walls on the internal comfort in the Polish 
climate. Energy Procedia, Vol. 78, pp. 1087-1092. doi: 10.1016/j.egypro.2015.11.058

2. Michalak P. (2019). Modelling of global solar irradiance on sloped surfaces in climatic conditions of Kraków. In: New Trends in Production Engineering, Vol. 2, No. 1, pp 505-514. doi: https://doi.org/10.2478/ntpe-2019-0054

3. Firląg S., Piasecki M. (2018). NZEB Renovation Definition in a Heating Dominated Climate: Case Study of Poland. Applied Sciences, Vol. 8, No. 9, 1605 doi:10.3390/app8091605

4. Krawczyk D.A. (2016). Analysis of Energy Consumption for Heating in a Residential House in Poland. Energy Procedia, Vol. 95, pp. 216-222. https://doi.org/10.1016/j.egypro.2016.09.053

5. Sikora M., Siwek K. (2018). Energy audit of the residential building. Journal of Mechanical and Energy Engineering, Vol. 2, No. 4, pp. 317-328. https://doi.org/10.30464/jmee.2018.2.4.317

6. Witkowska A., Krawczyk D.A., Rodero A. (2019). Investment Costs of Heating in Poland and Spain - A Case Study. Proceedings, Vol. 16, No. 1, 40. doi: 10.3390/proceedings2019016040

7. Pieczara J. (2016). Reasons for the growing popularity of energy efficient buildings in Poland. Infrastructure and Ecology of Rural Areas, No. IV/1/2016, pp. 1195-1207. https://doi.org/10.14597/infraeco.2016.4.1.087

8. Deja B.M., Tyburski J. (2015). Selected aspects of designing and realization of low energy single-family houses according to the NF15 and NF40 standards. Technical Sciences, Vol. 18, No. 2, pp. 103-114 http://uwm.edu.pl/wnt/technicalsc/tech_18_2/deja.pdf

9. Miszczuk A. (2017). Influence of air tightness of the building on its energy-efficiency in single-family buildings in Poland. MATEC Web of Conferences, Vol 117, Art. No. 00120. DOI:10.1051/matecconf/ 20171170012

10. PN-EN ISO 13790:2009 (2009): Energy performance of buildings. Calculation of energy use for space heating and cooling. The Polish Committee for Standardization

11. Vestfálová M., Šafařík P. (2018). Determination of the applicability limits of the ideal gas model for the calculation of moist air properties. EPJ Web Conferences, Vol. 180, Art. No. 02115. https://doi.org/10.1051/ epjconf/201818002115

12. Compendium of Chemical Terminology. IUPAC. https://doi.org/10.1351/goldbook.G02579

13. Picard A., Davis R.S., Glaser M., Fujii K. (2008). Revised formula for the density of moist air (CIPM-2007) Metrologia, Vol. 45, No. 2 pp. 149-155. doi:10.1088/0026-1394/45/2/004

14. Mohr P.J., Newell D.B., Taylor B.N. (2016). CODATA Recommended Values of the Fundamental Physical Constants: 2014. Journal of Physical and Chemical Reference Data, Vol. 45, No. 4, Art. No. 043102. DOI: $10.1063 / 1.4954402$

15. Berberan-Santos M.N., Bodunov E.N., Pogliani L. (1997). On the barometric formula. American Journal of Physics, Vol. 65, No. 4, pp. 404-412. https://doi.org/10.1119/ 1.18555

16. Andrews D.G. (2000). An Introduction to Atmospheric Physics. Cambridge. Cambridge University Press.

17. Kind M., Martin H. (Ed.). (2010). VDI Heat Atlas. Springer-Verlag Berlin Heidelberg.

18. PN-EN ISO 52016-1:2017 (2017): Energy performance of buildings - Energy needs for heating and cooling, internal temperatures and sensible and latent heat loads Part 1:Calculation procedures. The Polish Committee for Standardization

19. van Dijk D. (2018). EPB standards: Why choose hourly calculation procedures? REHVA Journal, No. 2, pp. 6-12. https://www.rehva.eu/rehva-journal/chapter/epbstandards-why-choose-hourly-calculation-procedures

20. Staszczuk, A. (2012). Comparison of the calculation results of heat exchange between a single-family building and the ground obtained with the quasi-stationary and 3-d transient models. Part 1: continuous heating mode. Civil and Environmental Engineering Reports, Vol. 1, No. 8, pp. 77-87. https://ceer.com.pl/resources/html/ article/details?id $=167780$

21. Lausten J. (Ed.). (2019). Implementing the Energy Performance of Buildings Directive (EPBD). Country Reports. https://epbd-ca.eu/wp-content/uploads/ 2019/09/ CA-EPBD-2018-BOOK-VOLUME-I.pdf

22. Grudzińska M., Jakusik E. (2016). Energy performance of buildings in Poland on the basis of different climatic data. Indoor and Built Environment, Vol. 26 No. 4, pp. 551566. https://doi.org/10.1177/1420326X16631031

23. Krużel J., Ziernicka-Wojtaszek A. (2016). Diversity of air temperature in Poland in the years 1971-2010. Journal of Ecological Engineering, Vol. 17, No. 5, pp. 227-231 DOI: $10.12911 / 22998993 / 65230$

24. Typical meteorological years and statistical climate data for Poland for energy calculations of buildings. [Accessed on 14 February 2020] https://dane.gov.pl/dataset/797, typowe- lata- meteorologiczne- i- statystyczne- daneklimatyczne- dla- obszaru- polski- do- obliczenenergetycznych- budynkow

25. PN-EN ISO 13786:2008 (2008): Thermal performance of building components - Dynamic thermal characteristics - Calculation methods. The Polish Committee for Standardization

26. PN-EN 12831:2017 (2017): Energy performance of buildings - Method for calculation of the design heat load. The Polish Committee for Standardization

27. Nowak S. (2009). Management of heat energy consumption in Poland for the purpose of buildings' heating and preparation of useable, hot water. Annales Universitatis Apulensis Series Oeconomica, Vol. 11, No. 2, pp. 895-901

28. Szczerbak K. (2019). Impact of location characteristics on renewable energy production for a group of buildings. E3S Web of Conferences, Vol. 116, Art. No. 00084. https://doi.org/10.1051/e3sconf/201911600084

29. Chwieduk D. (1999). Prospects for low energy buildings in Poland. Renewable Energy, Vol. 16, No. 1-4, pp. 11961199. https://doi.org/10.1016/S0960-1481(98)00472-8

30. Basińska M., Koczyk H., Kosmowski A. (2015). Assessment of thermo modernization using the global cost method. Energy Procedia, Vol. 78, pp. 2040-2045. doi: 10.1016/j.egypro.2015.11.204

31. Michalak P. (2019). New standards of PN-EN ISO 52000 family and monthly solar heat gains in residential buildings [in Polish]. Ciepłownictwo Ogrzewnictwo Wentylacja, Vol. 50, No. 2, pp. 50-55 DOI:10.15199/9.2019.2.2

\section{Biographical note}

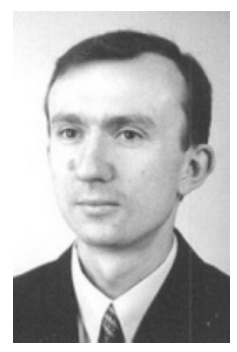

Piotr Michalak received Ph.D degree in Energy Machines and Equipment from AGH, Kraków. Since 2009 he has been a researcher in the Department of Power Systems and Environmental Protection Facilities at the AGH. His scientific interests involve thermal dynamics of buildings, utilisation of renewable energy sources, CFD simulations and thermal and flow measurements. 
